\title{
Assessment role of total phenols and flavonoids extracted from Pleurotus columbinus mushroom on the premature ovarian failure induced by chemotherapy in rats
}

\author{
Amal I. Hassan ${ }^{1}$, Mona A. M. Ghoneim', Manal G. Mahmoud² and Mohsen S. Asker ${ }^{2 *}$ (1)
}

\begin{abstract}
Background: Many species of mushroom contain an assortment of free radical scavengers (Phenolics and Flavonoids compounds) that have made them nutritionally beneficial and a source of expansion of drug production. In this study, we examined the preventive and remedial role of total phenol extract from Pleurotus columbines (TP) in alleviating the consequences of cyclophosphamide (CTX) on the ovaries of female rats. Rats were randomly assigned to four groups: healthy controls, cyclophosphamide (CTX), received a TP (100 mg/kg) orally daily for 14 days and curative group: CTX-TP, we determined and identified a total phenol from a mushroom extract and examined it as an antioxidant agent. To investigate the therapeutic influence, it was administrated 2 weeks after CTX. To assess the impact of TP on ovarian damage caused by CTX, ovarian hormone tests were performed such as luteinizing hormone $(\mathrm{LH})$, 17- $\beta$-estradiol (E2), and anti-mullerian hormone (AMH). Besides, follicle-stimulating hormone (FSH) in serum was evaluated, and histopathological analysis of the ovary was examined.
\end{abstract}

Results: This study indicates that treatment with TP decreased the severity of cyclophosphamide-induced ovary injury by reducing inflammation and apoptotic effects and increasing the activity of antioxidants.

Conclusions: TP could be used to alleviate cyclophosphamide-induced ovary injury.

Keywords: Cyclophosphamide, Mushroom, Flavonoids, Total phenols, Natural antioxidant

\section{Background}

Mushrooms such as Pleurotus sp. are considered therapeutic agents for over 100 years. Based on the presence of proteins, carbohydrates, vitamins, minerals, essential unsaturated fatty acids, aromatic phenols, terpenoids, steroids, and water content, one of these mushrooms has the highest biological nutritional value [1]. The Pleurotus has many active metabolites, which are sources of pharmaceuticals for several diseases, including hypertension, anemia, diabetes, obesity,

\footnotetext{
*Correspondence: mohsenmsa@yahoo.com

${ }^{2}$ Microbial Biotechnology Department, National Research Centre, Dokki, Giza, Egypt

Full list of author information is available at the end of the article
}

inflammatory, viral, mutagenic, and oxidant diseases [2]. The mushroom phenolics include benzoicacid, trans-3, 4-dihydride-3, 4, 8-trihydroxide, 1(2H)-one, 4-hydroxy benzaldehyde, and the flavonoids include quercetin, catechin, and chrysin (Papaspyrid). Besides dietary fibers, chitin, and glucans, mushrooms contain intrinsic cell-walls constituents such as riboflavin and other B-group vitamins, selenium, copper, and potassium, also dietary fibers, chitin, and potassium [3]. While mushrooms are the best dietary source of the extraordinary sulfur-containing antioxidants ergothioneine, the active antioxidant "glutathione" is evaluated [4]. Recently, acute dosing with CTX was shown to reduce ovarian follicles over 3 days in Sprague-Dawley 
rats [5]. Besides, an inhibitory effect of cyclophosphamide has been detected on the hypothalamic-pituitary axis in rhesus monkeys [6]. This finding shows ovarian failure itself as excessive gonadal insufficiency, leading to menopause and usually irreversible sterility. When all follicles containing the eggs are damaged, the chance of pregnancy becomes impossible. Various laboratory investigations have isolated compounds with benefits for humans from several mushrooms. Lee et al. [7] stated that eating mushrooms eliminates epithelial ovarian cancer in women in southern China, as this fungus protects against this type of cancer. Therefore, the present study was intended to appraise the antioxidant activity of an aqueous extract of $P$. columbinus and its impact on premature ovarian failure (POF) triggered by chemotherapy in rats.

\section{Methods}

\section{Mushroom sample collection}

A sample of dry Pleurotus columbinus was purchased from the Microbiological Culture Center (Cairo, Egypt) and used throughout the study period.

\section{Extraction of mushroom}

Dried powdered fruiting bodies (20 g) were extracted by stirring with $200 \mathrm{~mL}$ distilled water for $24 \mathrm{~h}$ and then centrifuged at $5000 \times g$ for 30 min using 2K15 SigmaLaborzentrifugen (Germany), and the supernatant was stored at $-20{ }^{\circ} \mathrm{C}$. The residue was re-extracted with 30 $\mathrm{ml}$ distilled water; the combined aqueous extracts were lyophilized.

\section{Mushroom composition}

The contents of crude protein, raw fiber, crude fat, and ash of the mushroom were assayed according to Association of Official Analytical Chemists (AOAC) methods. In addition, mushroom polysaccharide content was calculated using the phenol-sulfuric acid method of Lu et al. [8].

\section{Determination of total phenolic content}

The total phenolic content was determined using the spectrophotometer technique according to $\mathrm{Li}$ et al. [9]. First, the dried extract was dissolved in distilled water $(1 \mathrm{mg} / \mathrm{mL})$ and then $0.5 \mathrm{~mL}$ was added to $2.5 \mathrm{~mL}$ of $10 \%$ Folin-Ciocalteu reagent and $2 \mathrm{~mL}$ of $\mathrm{NaCO}_{3}(2 \% \mathrm{w} / \mathrm{v})$. The mixture was incubated at $45{ }^{\circ} \mathrm{C}$ with shaking for 15 min. Absorbance was measured at $765 \mathrm{~nm}$ using a UV/ VIS spectrophotometer (UV-1700 pharam sec, Shimadzu, Japan), and the phenolic content was quantified regarding a standard curve of gallic acid.

\section{Estimation of total flavonoids}

Flavonoids were assayed according to the colorimetric method of Li et al. [9]. To $1 \mathrm{~mL}$ of the mushroom extract, $3 \mathrm{~mL}$ methanol, $0.2 \mathrm{~mL}$ of $10 \% \mathrm{AlCl}_{3}, 0.2 \mathrm{~mL}$ of $1 \mathrm{M}$ potassium acetate, and $5.6 \mathrm{~mL}$ distilled water were added. The mixture was incubated at room temperature for 30 $\mathrm{min}$. The absorbance of the reaction mixture was measured at $415 \mathrm{~nm}$ using a UV/VIS spectrophotometer (UV1700 pharma sec, Shimadzu, Japan). Quercetin was used to calculate the standard curve.

\section{Designating phenolics by high performance liquid chromatographic (HPLC)}

The lyophilized mushroom extract was fractionated using liquid chromatography (Shimadzu corporation-Kyoto, Japan). This parathion was achieved at a reversed-phase C18 column $(250 \times 4.6 \mathrm{~mm}, 5$ microns $)$ temperature at $24{ }^{\circ} \mathrm{C}$. The mobile phase of the optimized chromatographic method comprised solvent A (methanol) and solvent $B \quad 0.5 \%(\mathrm{v} / \mathrm{v})$ acetic acid in water). Elution profile was 0 min $10 \%$ A in B, 28.6 min $60 \%$ A in B, 30 min $10 \%$ A in $B$. The flow rate was $1 \mathrm{~mL} / \mathrm{min}$, and the injection volume was $20 \mu \mathrm{l}$. By comparing the retention time of the eluted components to the retention time of the reference standard, the eluted components were recognized (systemcontrolled CMB-20A/20A liter). Phenolic compounds present in the samples were characterized according to their UV/VIS. Absorption was measured at $290 \mathrm{~nm}$.

\section{DPPH radical scavenging activity}

The $P$. columbinus extract $100 \mathrm{mg}$ was mixed with 10 $\mathrm{ml}$ methanol $(96 \%)$ and $63 \mu \mathrm{moL} / \mathrm{L}$ of the alpha-diphenyl-beta-picrylhydrazyl (DPPH) solution to assess the fungal extract's ability to scavenge the stable free radical DPPH. After different times (at 30,60, and $90 \mathrm{~min}$ ) at room temperature, the absorbance was measured at 517 $\mathrm{nm}$ and expressed as radical scavenging capacity according to Zeković et al. [10]. The radical scavenging capacity (RSC) was calculated using the following equation:

$$
\mathrm{RSC}=\mathrm{Ac}-\mathrm{As} / \mathrm{Ac} \times 100
$$

where Ac is the absorbance of the control; As is the absorbance of the sample.

\section{In vivo study \\ Experimental design}

Wistar rats have been purchased from the laboratory animal colony. Thirty-two adults' female Wistar rats, weighing 150-180 g and aged 10-13 weeks, were kept in the animal care facility. Rats were fed and watered according to the regular diet for rats with a 12-h light-dark cycle. 


\section{Chemicals}

Cyclophosphamide (CTX) The experimental CTX was represented as a vial of $200 \mathrm{mg}$ from Baxter Oncology $\mathrm{GmbH}$, Halle. The medication was dissolved in $10 \mathrm{ml}$ of saline buffer phosphate.

\section{Enhancement POF}

Cyclophosphamide was implanted in rats by intraperitoneal injection (IP) at a rate of $50 \mathrm{mg} / \mathrm{kg}$ of body weight as a loading dose, followed by CTX IP $(8 \mathrm{mg} / \mathrm{kg})$ injection daily for 2 weeks [11].

\section{Animals' groups}

We randomly assigned the animals into four groups: group I: control group $(n=8)$ : received vehicle solution as $200 \mathrm{ppm}$ saline; group II: CTX group $(n=8)$ : injected with CTX as specified above; group III: normal rats treated with lyophilized TP $(100 \mathrm{mg} / \mathrm{kg})$ orally for two consecutive weeks. Group IV (curative group): CTX-TP $(n=8)$; this group received CTX $(8 \mathrm{mg} / \mathrm{kg}$ body weight, IP) for 14 days and then they received TP $(100 \mathrm{mg} / \mathrm{kg})$ orally for two consecutive weeks, starting from the next day post CTX (from 15th to 28th of the experiment). We followed the guidelines of the Institutional Animal Ethics Committee regarding experimental research in small animals. Therefore, the rats were anesthetized by Na-pentobarbital (60 mg/kg i.p.) before blood was sampled.

\section{Blood assays and tissue sampling}

At the end of the experiment (29th day, the next day post $\mathrm{TP})$, rats were subjected to anesthesia Na-pentobarbital $(60 \mathrm{mg} / \mathrm{kg}$ i.p.), and an approximately $5 \mathrm{ml}$ of blood samples were obtained from the orbital venous plexus in clean sealed tubes. Blood samples were centrifuged to sera at $3000 \times g$ for $10 \mathrm{~min}$. The ovary was quickly excised, washed out with normal saline, blotted with filter paper, weighed, and put into ice-cold saline $(0.9 \% \mathrm{NaCl})$. Approximately, 50-100 mg of ovary tissue was hydrolyzed in $600 \mu \mathrm{L}$ of lysis buffer saline (pH 7.4) with an Ultra-Tur$\operatorname{rax}$ T-25 homogenizer (IKA ${ }^{\circledR}$, Staufen, Germany). The homogenate was centrifuged at $10,000 \times g$ and $4{ }^{\circ} \mathrm{C}$ for 10 min, and the supernatant was used up for testing the oxidative stress enzymatic biomarkers.

\section{Measurement of lipid peroxidation}

The thiobarbituric acid reactant assay (TBARS) was estimated to detect lipid oxidation. Malondialdehyde (MDA), a split product of an endoperoxide from an unsaturated fatty acid resulting from the oxidation of lipid substrates. One hundred microliters of the samples were placed in microcentrifuge tubes. After that, $100 \mu \mathrm{l}$ of SDS lysis solution was added to each microcentrifuge tube, which was then incubated at room temperature for $5 \mathrm{~min}$. After the incubation, $250 \mu \mathrm{L}$ of TBARS was added, followed by a $45-60 \mathrm{~min}$ re-incubation at $95{ }^{\circ} \mathrm{C}$. All the samples were centrifuged at $554 \times g$ for 15 min after cooling in an ice bath for $5 \mathrm{~min}$. The supernatants and MDA standards $(200 \mu \mathrm{L})$ were placed in separate microplates, and the absorbance at $532 \mathrm{~nm}$ was measured.

\section{Assessment of the oxidative stress enzymes}

The ovarian antioxidant enzymes, including superoxide dismutase (SOD) [12], catalase (CAT) [13], and glutathione peroxidase (GPx) [14], were estimated using ELISA kits (Randox Laboratories, UK). The glutathione (GSH) was also assessed by the same protocol using commercial kits purchased from Northwest Life Science Specialties LLC (Washington, USA). Supernatant (from the ovarian samples that have been homogenized in PBS at $10000 \times g$ on the ice for $5 \mathrm{~min}$ ) and the antioxidant standards $(20 \mu \mathrm{L})$ were added into respective wells. Each samples and antioxidant standards were run in duplicate.

\section{TNF-a serum measurement}

A TNF- $\alpha$ sample level was measured using commercially available kits (Awareness Technology Inc., Chro Mate ELISA Reader; Cambridge, UK) by an enzymelinked immunosorbent assay (ELISA). TNF- $\alpha$ levels were expressed in $\mathrm{pg} / \mathrm{ml}$.

\section{Anti-Mullerian hormone (AMH) serum levels}

The ELISA (Thermo Science Multiskan GO, Finland) was used to evaluate AMH (ng/mL) levels of the serum samples. The sensitivity of the analysis was recorded at 0.10 $\mathrm{ng} / \mathrm{mL}$ assay with the test range of $0.3-40 \mathrm{ng} / \mathrm{mL}$.

\section{Radioimmunoassay for serum $L H, F S H$, and E2}

Homologous double-antibody radioimmunoassay techniques were used to quantify LH, FSH (100 $\mu \mathrm{L}$ of serum), and E2 in $50 \mu \mathrm{L}$ of serum [15]. DI Asource ImmunoAssays S.A. (Rue de l'Industrie, B-1400 Nivelles, Belgium) was used to measure E2 (KIP0629), FSH (KIP0841), and LH (KIP1311) levels.

\section{Analysis of Western blot}

The immunoprobing of Western blots was used to measure the level of ovarian caspase- 3 protein. The STE buffer $(0.32 \mathrm{~mol} / \mathrm{L}$ sucrose, $5 \mathrm{mmol} / \mathrm{L}$ tris, $2 \mu \mathrm{g} /$ $\mathrm{mL}$ leupeptin), centrifuged at $4{ }^{\circ} \mathrm{C}$, was made in $10 \mathrm{~min}$, with $10 \%(\mathrm{w} / \mathrm{v})$, and tissue homogenates $(0.32 \mathrm{~mol} / \mathrm{L}$ sucrose). The buffer was then centrifuged at $4{ }^{\circ} \mathrm{C}$. In SDS sample buffers (50 mm Tris pH 7.5, 5\% SDS, $5 \mathrm{mM}$ DTT, 5\% Glycerol), $6 \mathrm{M}$ Urea was removed by centrifugation $(14,000 \times g, 20 \mathrm{~min})$, and the cell pellets were 
separated by heating $\left(95{ }^{\circ} \mathrm{C}, 5 \mathrm{~min}\right)$, which included a sample buffer of SDS. Supernatants were tested with the Bio-Rad DC Protein Assay for protein content and processed until use at $-80{ }^{\circ} \mathrm{C}$. These protein extracts were transmitted to the nitrocellulose membranes (Amersham Life Science, Little Chalfont, UK) utilizing a system of mini-protein electrophoresis $(30 \mathrm{~V}, 16 \mathrm{~h})$. Membranes were blocked overnight at raw fiber with 3\% $(\mathrm{w} / \mathrm{v})$ bovine serum albumin (BSA) in $0.1 \%(\mathrm{v} / \mathrm{v})$ Tween 20 TBS (TTBS) before being probed for $2 \mathrm{~h}$ at room temperature with a polyclonal rabbit anti-rat caspase-3 (Santa Cruz Biochemicals, USA) at 1:2000 dilutions in TTBS buffer. An anti-rabbit peroxidase conjugate was diluted at 1:2000 in TTBS buffer for $1 \mathrm{~h}$. Then, the ECL chemiluminescent detection system was used to reveal primary antibody binding (Life Science). Recombinant Caspase-3 was used to test the antibody effectiveness under experimental circumstances (Sigma) canning densitometers of the Bio-Rad GS-690. The software versions 4 Molecular Analyst were assessed for the volume density (Bio-Rad Laboratories Ltd., Hertfordshire, UK). Compared with protein molecular weight markers (BioRad Laboratories Ltd.), the translation size was calculated using the same analysis tool.

\section{DNA fragmentation by agarose gel electrophoresis}

Ovarian tissues $(10 \mathrm{mg})$ were homogenized from the animal in each group and used for DNA isolation by PBS-E homogenization (50 $\mathrm{mM}$ sodium phosphate buffer containing $0.9 \%$ saline and $20 \mathrm{mM}$ EDTA, pH 8). DNA was suspended in $2 \mathrm{~mL}$ PBS-E with a collagenase of $0.5 \mathrm{mg} / \mathrm{ml}$. The Ultra Turrax homogenizer (IKA T 25-German) was employed, and ice testing specimens before and after homogenization were maintained. First, a stirring accompanied by a pronase $\mathrm{E}$ addition $(1 \mathrm{mg} /$ $\mathrm{mL}$ ) for $1 \mathrm{~h}$ was incubated with a stirring at $37^{\circ} \mathrm{C}$ and then incubated for $15 \mathrm{~min}$ at $37^{\circ} \mathrm{C}$. Then, the suspension was centrifuged at $1000 \times g$ for $5 \mathrm{~min}$. Next, a pellet with $2 \mathrm{ml}$ lysis buffer containing $50 \mathrm{~m}$ MTris- $\mathrm{HCl}, \mathrm{pH}$ 8, $20 \mathrm{mM}$ EDTA, $10 \mathrm{M} \mathrm{NaCl}$, and 1\% (w/v) SDS were dispersed and infused and again centrifuged for $15 \mathrm{~min}$, at $14,000 \times g$, with phenol-chloroform extraction [16] of the pellet extracted from the lysate. Next, at $65{ }^{\circ} \mathrm{C}$ at $10 \mathrm{mM}$ Tris- $\mathrm{HCl}, \mathrm{pH} 8$, containing $1 \mathrm{mM}$ EDTA, DNA was dissolved by gentle shaking. Next, $2 \%$ agarose gel was prepared as $1 \mathrm{~g}$ of agarose was dissolved in $50 \mathrm{~mL}$ of Tris-Acetate EDTA (TAE) buffer in a flask covered with an aluminum sheet for 5 min microwave adjustable to medium temperature for the study of DNA fragmentation. In addition, $2.5 \mu \mathrm{l}$ of ethidium bromide (EB) was added to the agarose solution chilled to $60{ }^{\circ} \mathrm{C}$ to allow the visualization of DNA. Gloves were required in dealing with EB dye solutions because it is a highly sensitive mutagen. The gel was spilt into a pure, dry gel mold. The comb was gently eliminated, and the gel was placed in the electrophoresis chamber when the agarose had set (20-30 min).

\section{Histological examination}

Hematoxylin and eosin (H\&E) staining was performed to test for ovarian damage by Bova et al. [17]. Ovarian samples from all groups were fixed in $10 \%$ formalin for $48 \mathrm{~h}$, and paraffin blocks were prepared. Each sample was cut at $5 \mu \mathrm{M}$, and the slides were covered with polylysine. Then, paraffin was removed from each slide in xylene, hydrated with different downward concentrations of ethanol, and stained in hematoxylin. Then, the slides were stained from the eosin counter, dried, and placed in increasing concentrations of ethanol and xylene. Pictures were taken under a microscope. Ovarian follicles were counted in each slide, according to Maciel et al. [18] with the help of the Leica Qwin 500 LTD image analysis software (Cambridge, UK).

\section{Smear of vagina}

In the early morning, vaginal secretion was obtained by injecting a plastic pipette filled with $10 \mu \mathrm{l}$ of regular saline $(0.9 \% \mathrm{NaCl})$ into the vagina of the rat, using the presence of cornified cells as an indication of estrogenic activity [19].

\section{Statistical analysis}

The findings were expressed as mean \pm SEM. For statistical analysis, one-way analysis of variance accompanied by using the Tukey Multiple Comparison tests as a post hoc test was used, where $P<0.05$ was the agreed standard of statistical significance.

\section{Results}

The results illustrated that the mushroom $P$. columbinus was rich in carbohydrates and protein $(43.0 \%$ and $17.0 \%$, respectively) but low in fiber and fat $(2.5 \%$ and $4.5 \% \mathrm{DW}$, respectively) with an ash content of $5.7 \%$ DW.

\section{Total phenolics and flavonoids compounds}

The amount of $28.13 \mathrm{mg} / \mathrm{g}$ gallic acid equivalent $/ \mathrm{mL}$ of extract was found. The total phenolic and total flavonoid literature of mushroom were low compared to previous data from literature of Pleurotus species $(45.6 \mathrm{mg} / \mathrm{g})$. The total flavonoids content of P. columbinus was observed as $6.6 \mathrm{mg}$ quercetin equivalent/g of extract.

\section{Phenolic compound identification by HPLC}

Phenolic compounds include different subclasses, and they displayed a large diversity of structure. We found catechin $(32.77 \mu \mathrm{g} / \mathrm{mL})$, gallic acid $(21.86 \mu \mathrm{g} / \mathrm{mL})$, rutin 


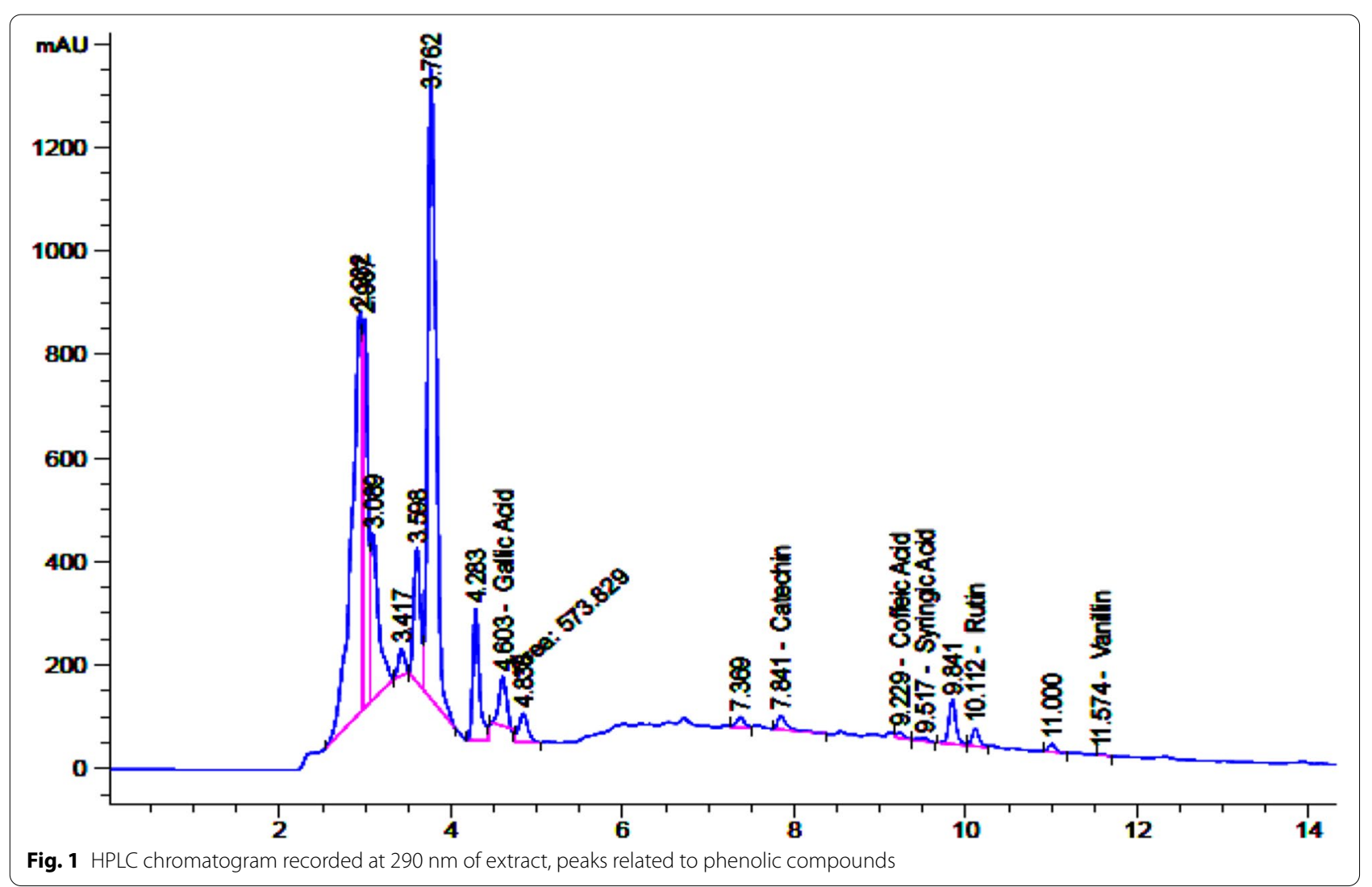

$(13.34 \mu \mathrm{g} / \mathrm{mL})$, vanillin $(0.23 \mu \mathrm{g} / \mathrm{mL})$, syringic acid $(1.64$ $\mu \mathrm{g} / \mathrm{mL})$, and coffeic acid $(1.61 \mu \mathrm{g} / \mathrm{mL})$ are present in the sample at retention times $7.84,4.60,10.11,11.57,9.51$, and 9.22 min respectively. These compounds were identified (Fig. 1) from TP by comparing their chromatographic characteristics with the standards compounds.

\section{DPPH radical scavenging activity}

The present study proved the DPPH scavenging activity of phenolic extract at different times $0,30,60$, and 90 min. The antioxidant activity was increased with increasing time. The maximum scavenging activity (90.21\%) at $0.1 \mathrm{mg} / \mathrm{mL}$ was observed after $90 \mathrm{~min}$.

\section{In vivo results}

\section{Body, ovarian, and uterine weight changes}

After 14 days of administered CTX, the rats lost approximately 1.28 -fold their body weight compared to the control group $182 \pm 8.13$ and $142.22 \pm 5.40$ $\mathrm{g}$, respectively (Table 1 ). Likewise, the same effect happened on the ovarian and uterine weight, where they lost about 2.02 and 1.92-folds, respectively, compared to the control group (Table 1). Moreover, a significant increase in CTX-treated groups and significant depression in both groups receiving TP before and after CTX in body weight amount 1.33fold also ovary and uterine wet weight amount to

Table 1 The antagonistic effect of P. columbinus extract in alleviating the toxic effect of CTX on body weight, ovary, and uterine weights of rats

\begin{tabular}{llll}
\hline Groups & Body weight $(\mathbf{g})$ & Ovarian weight $(\mathbf{m g})$ & Uterine weight $(\mathbf{m g})$ \\
\hline Control & $182 \pm 8.13^{\mathrm{b}}$ & $88.16 \pm 6.75^{\mathrm{a}}$ & $119.33 \pm 10.11^{\mathrm{a}}$ \\
CTX & $142.22 \pm 5.40^{\mathrm{c}}$ & $43.70 \pm 3.54^{\mathrm{c}}$ & $62.15 \pm 8.32^{\mathrm{c}}$ \\
P. columbinus extract & $204.32 \pm 11.52^{\mathrm{a}}$ & $84.67 \pm 5.68^{\mathrm{a}}$ & $112.72 \pm 9.67^{\mathrm{a}}$ \\
CTX + P. columbinus & $189.17 \pm 9.04^{\mathrm{bc}}$ & $75.81 \pm 5.43^{\mathrm{b}}$ & $97.17 \pm 7.36^{\mathrm{b}}$
\end{tabular}

Each value represents mean $\pm \mathrm{SE}(n=8) . \mathrm{a}, \mathrm{b}, \mathrm{ab}$, and c denote significant difference from normal-control, CTX-induced POF, $P$. columbinusextract control and POF $+P$. columbinus (before and after) groups, respectively, $p<0.05$ (one-way ANOVA followed by post hoc Tukey) 
1.73 and 1.56-folds, respectively compared to the CTX group (Table 1). Thus, although ovarian and uterine weights were increased in the mushroom extract-treated group and were significantly higher than in the CTX group, they were still somewhat lower than in the control group.

\section{Serum hormones evaluation}

Table 2 shows that the CTX group had early ovarian failure resulting in serum AMH and E2 levels of 2.45 and 2.77-folds lower than the control values, respectively. Likewise, LH levels were approximately 2.32-folds lower than the control group in rats with premature ovarian failure. However, the results recorded a remarkable increase in these parameter treatments with mushroom extract (Table 2). Regarding the level of $\mathrm{FSH}$, there was a significant $(p<0.05)$ increase by 1.59 fold $(6.65 \pm 0.18)$ in the CTX animals after 14 when compared to the control group $(4.17 \pm 0.07)$ (Table 2$)$. However, administrations of the mushroom extract improved the level of FSH with values of $4.75 \pm 0.31$ (28.60\%) lower than the CTX group and are close to the control values.

Table 2 The antagonistic effect of $P$. columbinus extract in alleviating the toxic effect of CTX on serum hormone levels in the experimental rats

\begin{tabular}{lllll}
\hline Groups & E2 (pg/ml) & $\begin{array}{l}\text { AMH }(\mathbf{n g} / \\
\mathbf{m l} /)\end{array}$ & FSH $(\mathbf{m l U} / \mathbf{m l})$ & LH $(\mathbf{m l U} / \mathbf{m l})$ \\
\hline Control & $11.05 \pm$ & $7.10 \pm 0.50^{\mathrm{a}}$ & $4.17 \pm 0.07^{\mathrm{bc}}$ & $1.30 \pm 0.02^{\mathrm{a}}$ \\
& $0.78^{\mathrm{a}}$ & & & \\
CTX & $4.51 \pm 0.33^{\mathrm{b}}$ & $2.56 \pm 0.04^{\mathrm{b}}$ & $6.65 \pm 0.18^{\mathrm{a}}$ & $0.56 \pm 0.01^{\mathrm{c}}$ \\
TP & $12.13 \pm$ & $7.16 \pm 0.62^{\mathrm{a}}$ & $3.93 \pm 0.06^{\mathrm{c}}$ & $1.27 \pm 0.007^{\mathrm{ab}}$ \\
& $1.35^{\mathrm{a}}$ & & & \\
CTX+TP & $12.30 \pm$ & $6.30 \pm 0.41^{\mathrm{a}}$ & $4.75 \pm 0.31^{\mathrm{b}}$ & $1.14 \pm 0.02^{\mathrm{b}}$ \\
& $1.58^{\mathrm{a}}$ & & & \\
\hline
\end{tabular}

Each value represents mean $\pm \mathrm{SE}(n=8)$. a, b, ab, and c denote significant difference from normal-control, CTX induced POF, P. columbines extract control and $\mathrm{POF}+P$. columbinus (before and after) groups, respectively, $p<0.05$ (oneway ANOVA followed by post hoc Tukey)
The effect of the mushroom extract on ovarian antioxidants, TBRAs, and TNF- $a$

The improving role of mushroom extract in POF induced by exposure to CTX was evident in the ovarian antioxidant enzymatic activities and the lipid peroxidation represented by TBARS (Table 3$)$. A significant $(p<0.05)$ decrease in the levels of SOD, CAT, GSH, and GSH-PX were observed after receiving CTX. These reductions in the antioxidants were 2.25, 2.43, 2.29 and 2.39-fold, respectively, compared to the controls. In addition, the decrease in the antioxidants was associated with a significant increase in TBRAs ( $p<0.05,4.57$-fold) compared to the control rats. However, administration of the mushroom extract significantly $(p<0.05)$ improved concentrations of these defensive enzymes and decreased TBRA levels (Table 3).

Figure 2a shows the effect of CTX and treatment with TP in rats. Using chemotherapy resulted in a significant increment in the TNF- $\alpha$ by about 4.47-fold compared to the control group. The administration with TP at a 100 $\mathrm{mg} / \mathrm{kg}$ concentration after 14 days showed the ameliorative effect in TNF-a. It led to a notable decrease of $\sim 3.72$ fold compared to the CTX group that did not receive the mushroom extract (TP).

\section{Ovarian DNA and caspase-3}

The harmful apoptotic effects of the animal rats exposed to CTX were mainly detected in this study using the DNA fragmentation technique (Fig. 2b). The DNA ladder depicted a sequence of fragments that are multiples of $180 \sim 200 \mathrm{bp}$. Compared to the control, the diffuse pattern of the DNA fragments in the CTX was distinct. The current study showed a marked rise in the CTX group of 5.14 folds compared with controls in the case assessment of caspase-3 (Fig. 2c). Contrarily, there was a marked amendment in DNA fragmentation after treatments with the different concentrations of $P$. columbinus extract (Fig. 2b).

\section{Histopathological findings}

The treatment of TP has reinforced the improvement of ovarian follicular failure caused by CTX, as shown

Table 3 The antagonistic effect of $P$. columbinus extract in alleviating the toxic effect of CTX on oxidative stress markers in the experimental rat groups

\begin{tabular}{|c|c|c|c|c|c|}
\hline Groups & TBRAS (nmol/ml) & CAT (U/g) & SOD (U/g) & GSH (U/mg) & GSH PX (U/g) \\
\hline Control & $0.37 \pm 0.02^{b}$ & $14.70 \pm 1.67^{\mathrm{a}}$ & $84.03 \pm 6.09^{a}$ & $10.27 \pm 0.81^{a}$ & $10.23 \pm 0.56^{a}$ \\
\hline CTX & $1.69 \pm 0.05^{a}$ & $6.05 \pm 0.54^{b}$ & $37.33 \pm 3.41^{b}$ & $4.48 \pm 0.33^{b}$ & $4.28 \pm 0.06^{b}$ \\
\hline $\mathrm{TP}$ & $0.39 \pm 0.03^{b}$ & $14.13 \pm 1.32^{\mathrm{a}}$ & $90.70 \pm 5.23^{a}$ & $10.02 \pm 0.63^{a}$ & $10.01 \pm 0.71^{a}$ \\
\hline$C T X+T P$ & $0.54 \pm 0.04^{b}$ & $13.90 \pm 1.12^{\mathrm{a}}$ & $75.83 \pm 3.44^{\mathrm{a}}$ & $8.92 \pm 0.41^{\mathrm{a}}$ & $9.993 \pm 0.56^{\mathrm{a}}$ \\
\hline
\end{tabular}

Each value represents mean $\pm \mathrm{SE}(n=8)$. a and b denote significant difference from normal control, CTX induced POF, $P$. columbines extract control and POF $+P$. columbinus (before and after) groups, respectively, $p<0.05$ (one-way ANOVA followed by post hoc Tukey) 


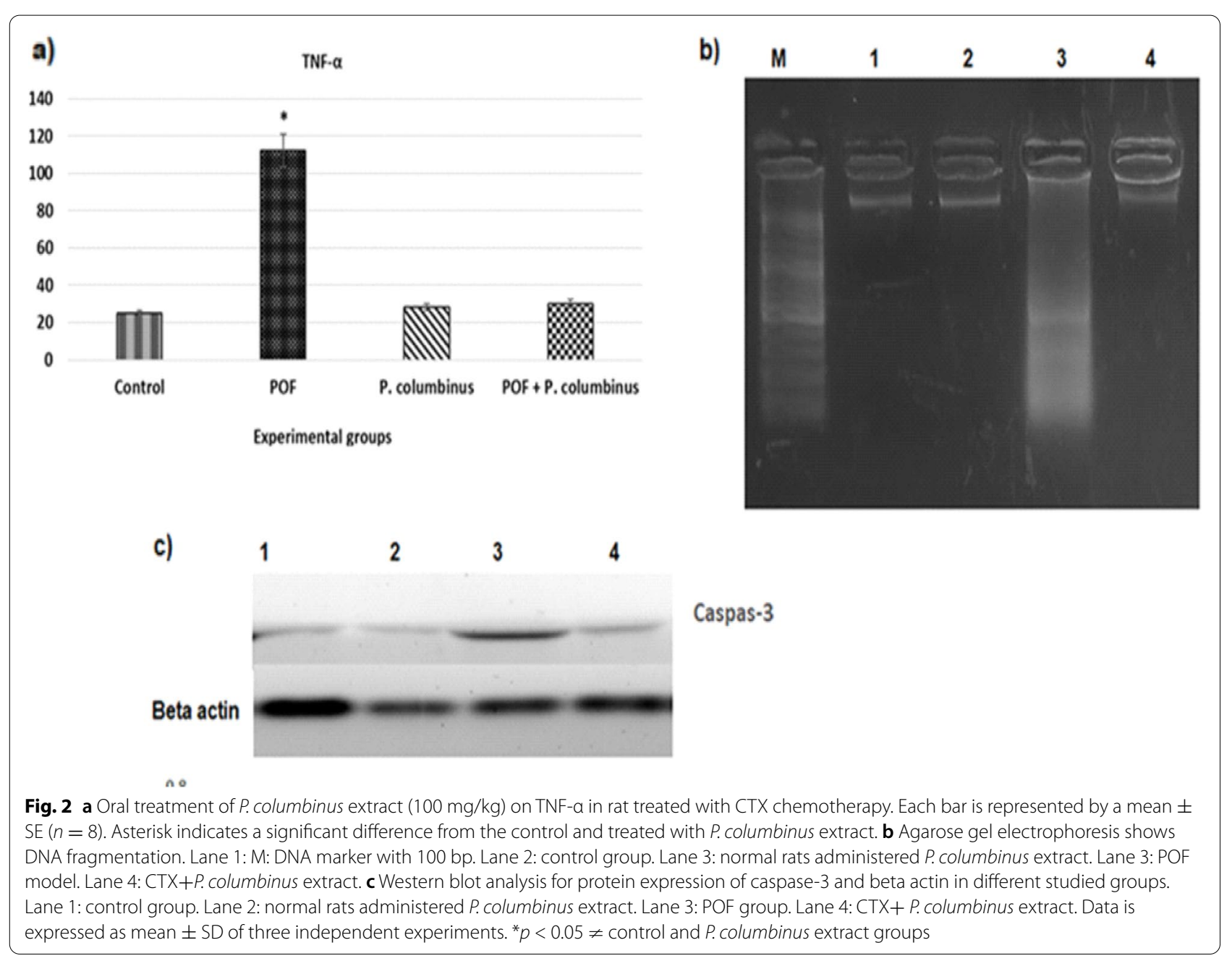

in Fig. $3 \mathrm{~h}$ and i.Several rising follicles (primordial, preantral, and antral) and ordinary granulosa cell layers (Fig. 3h and i) at various stages. It is noteworthy that the number of follicles and the primary, mature, and secondary follicles in the CTX group became fewer than the control group by about 2.44, 2.47, and 4.28-folds, respectively (Fig. 3j). Treatment with TP worked to overcome the effect of chemotherapy on the number of follicles in their different stages. The numbers of primary mature and secondary follicles increased by about 2.34 , 2.03, and 3.37-folds, respectively, compared to those left untreated.

\section{Vaginal smear}

In the postoperational cycle (100\% frequency), all animals displayed estrogen activity at the end of TP treatment (GIII and GIV).

\section{Discussion}

The main contents of TP are the total carbohydrate, total protein, total lipid, crude fiber, and ash content. Daba et al. [20] reported that carbohydrates represent the essential constituent in Pleurotus species ranging from $50-80 \%$. The protein content in the analyzed mushroom was $16.99 \%$. This value is between mushrooms from Chihuahua, Mexico (12.95-33.73\%) [20]. In Pleurotus florida, the total carbohydrates, fat, protein, fiber, and ash were $32.08,1.54,27.12,23.18$ and $9.41 \%$, respectively.

The mushroom has a significant nutritional value, with high protein concentration and a small quantity of total fat produced by its constituents [20]. Strain, growth media composition, harvest timing, management strategies, handling circumstances, and substrate preparation were all factors affecting mushroom characterizations [21]. The findings were like analysis by Bellettini et al. [22]. 


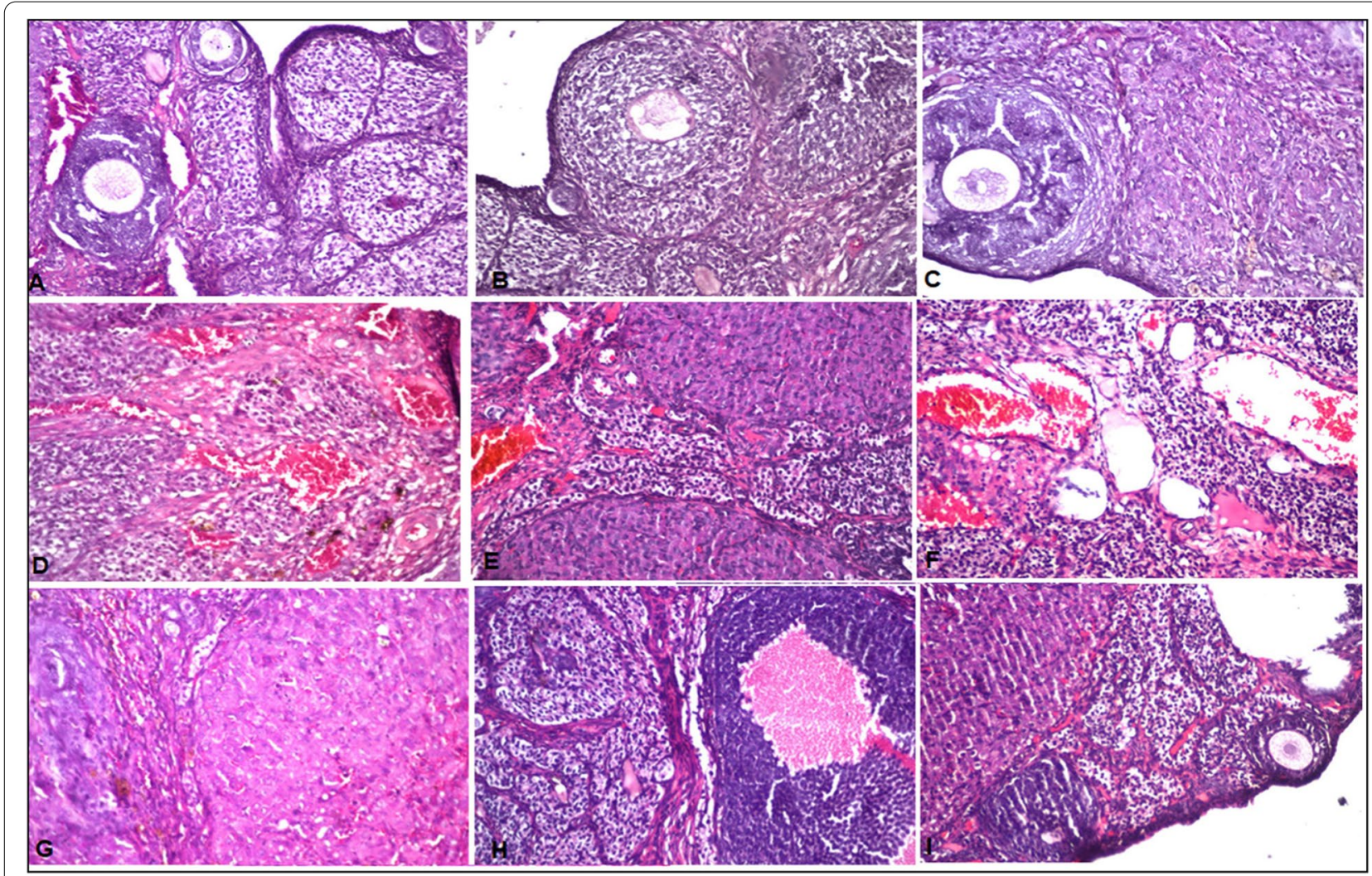

Fig. 3 a Control group: Interstitial stromal cells with primary and secondary follicles and few corpus luteum were detected (a and b). c Control rats received $P$. columbinus extract; there is no alteration in the primary and secondary follicles. $\mathbf{d}$ Group of rats injected CTX: Sever congestion was detected in the medullary blood vessels associated with mature follicle and corpus luteum in the cortex. There was congestion in the medullary portion associated with few atretic follicles as well as multiple corpus luteum (e). There was multiple corpus luteum with few follicles as well as interstitial stromal cells in the cortex. Sever congestion was detected in the medullary blood vessels. There was multiple corpus luteum with few follicles as well as interstitial stromal cells in the cortex (e and $\mathbf{f}$ ). Sever congestion was detected in the medullary blood vessels $(\mathbf{g})$. (h and $\mathbf{i})$ CTX+ P. columbinus extract (100 mg/kg): Interstitial stromal cells with normal primary and secondary follicles. $\mathbf{j}$ Oral treatment of P. columbinus extract (100 $\mathrm{mg} / \mathrm{kg}$ ) on the number of follicles in rats treated with CTX chemotherapy

\section{Total phenols}

Phenolic compounds are a substantial number of plant secondary metabolites with antioxidant properties that can act as free radical scavengers, hydrogen donors, and singlet oxygen quenchers, all of which are important in the redox reaction's defensive strategy. Many studies have shown that mushrooms have scavenging potential, farther they contain many phenolics that are indispensable plant constituents [23]. Phenolics also have a considerable variety of biological effects, including antibacterial, anti-inflammatory, and antihyperglycemic effects [24]. In this study, the amount of phenolic content of mushroom was the difference could be attributed to genetic factors, extraction time, temperature, and type of solvent.

\section{Total flavonoids}

Rengasamy et al. [25] reported that flavonoids are phenolic compounds that make up the most prevalent distributed phenolic group in plants. Besides, anthocyanidins, chalcones, flavanols, flavanones, flavones, flavanols, and isoflavone are major flavonoid classes. The total flavonoid content (TFC) varies depending on the mushroom species. The results were comparable to those reported by Palacios et al. [26], who declared that, among eight edible mushrooms, Lactarius deliciosus had a higher amount of total flavonoids. Besides, diversified values of TFC were found to have higher levels of flavonoids than the other species in five edible mushroom species, including Agaricus sivaticus [27].

\section{Antioxidant activities of TP}

The phenols are one of the considerable contributors to the antioxidant activity of different mushrooms [28]. Its ability to impart a hydrogen atom or an electron represented by its captive action of the $\mathrm{DPPH}$-free radical measured the antioxidant activities of the plant extract used in our study, as diphenyl-2-picryl-hydrazine, stable free radicals. In comparison with the antioxidant ability 
of various extracts of edible mushrooms (Pleurotus), these findings can be regarded as high antioxidant capacity [29]. Aryal et al. [30] suggested that phenolic and flavonoid groups are highly responsible for the antioxidant activity of the selected plant extract, not one component of them due to correlation of total phenolic and flavonoid content with antioxidant capacity. We need further studies to recognize that the phenolic compounds take the antioxidant activities and the mechanism of the phenolic compounds as an antioxidant. Also, in vivo antioxidant assays are required to confirm the potential use of this phenolic extract of mushrooms in the therapy of different diseases.

\section{In vivo findings}

The serum E2 level decreased in this post-CTX sample, correlated with a substantial increase in FSH compared to the healthy group, and these data show the existence of standard POF. Our findings were compatible with those of the previous study [31], which had proved this. The administration of TP substantially increased the hormonal changes resulting from cyclophosphamide intake used to treat cancer.

Our findings were compatible with those of the previous study [32]. By destroying ovarian tissue, chemotherapy has a detrimental effect on the ovaries.

A study had previously established that cyclophosphamide destroyed primordial follicles in proportion to the increased dose [33]. Besides, AMH was assessed in the various treatment groups because the evaluations of FSH and E2 could not express the capacity of the ovary to provide egg cells and fertilization before infertility development. The anti-Mullerian hormone is a hormonal protein that is produced by follicle cells [34]. Serum $\mathrm{AMH}$ has been suggested as a biomarker for ovarian syndrome diagnosis since it corresponds with the total number of antral follicles on both ovaries. These findings were consistent with human and experimental studies that previously recorded depressed AMH levels after chemotherapy or radiation [33].

Interestingly, TP approximately overwhelmed these faults caused by 14-day chemotherapy. The higher FSH levels reported after gonadotoxic treatment revealed a decline in ovarian function, consistent with reduced $\mathrm{AMH}$ levels [35]. In rats undergoing CTX therapy, we also evaluated different follicular numbers. In contrast to the control group, substantial depletion of the primordial follicle pool was observed. Our findings were consistent with a previous study that showed that primordial follicles are recruited at a more accelerated rate in the absence of $\mathrm{AMH}$, resulting in premature depletion of the primordial follicle population [30].
Interestingly, in rats treated with $P$. columbinus extract, ovarian vesicle clusters improved compared to rats treated with chemotherapy (POF). Two pathways followed adverse effects caused by CTX; direct and indirect [32]. The direct approach is happened through DNA ionization, while the indirect process generated reactive oxygen species (ROS). In the present study, the assessment of ovarian DNA fragmentation and caspase- 3 revealed a significant increase cleaved in CTX rats compared to the control group.

Results from a previous study showed that CTX toxicity increased ovarian tissue lipid oxidation and TBRA levels. These results were interpreted based on the principle of free radical formation during chemotherapy treatment due to leakage of electrons from the inner mitochondrial membrane during oxidative phosphorylation and generation of steroid ATP [36]. Oxidative stress disrupted cellular redox circuits, leading to disturbances in the redox-regulating cellular processes. Therefore, these free radicals interact with cellular lipids, proteins, and nucleic acids, thus preventing the development of $\mathrm{H}_{2} \mathrm{O}_{2}$ steroids in ovarian cells, eventually leading to ovary failure at various stages to shape its cells and follicles [37].

In our study, the GSH, GSH-PX, CAT, and SOD activities in the ovaries were significantly depleted. Besides, lipid peroxides were significantly increased after receiving CTX. However, the administration of TP for 14 days could improve antioxidant levels compared to groups with early ovarian failure from chemotherapy. Furthermore, a recent study has shown that resistance to the toxic effect of chemotherapy by modifying antioxidants [33]. Therefore, our research illustrated that countering oxidative stress and a lipid peroxidation is an extra tool through which TP can preserve the CTX-induced ovarian follicle failure.

\section{Conclusions}

The data of this study showed the chemical structure of $P$. columbinus extract and its containment of total phenols and flavonoids. Thus, these compounds improved the experimentally induced premature ovarian failure syndrome in female rats through their role as antioxidants and their effect on female sex hormones. The histological study of the ovaries also confirmed these biochemical results, as the administration of mushroom extract led to a clear improvement of ovarian tissue. Therefore, through experience, the efficacy of the $\mathrm{TP}$ is explicit in the recovery from early ovarian failure. We recommend conducting future clinical trials on this fungus because of its nutritional and therapeutic importance. TP may be expected as a possible promising medicinal for ameliorating the POF and its related oxidative damages. Subsequently, encouraging healthbeneficial effects makes it a potentially valuable natural 
candidate for the pharmaceutical industries worthy of further research in this area. The examination of bioactive components in edible mushrooms is still insufficient. Mushrooms with nutraceutical and health benefits are given various potential characteristics, which deserve further investigation.

\section{Abbreviations}

CTX: Cyclophosphamide; AMH: Anti-Mullerian hormone; LH: Luteinizing hormone; FSH: Follicle-stimulating hormone; TBARS: Thiobarbituric acid reactant assay; MPA: Malondialdehyde; TBA: Thiobarbituric acid; GPx: Glutathione peroxidase; SOD: Superoxide dismutase; CAT: Catalase; LLC: Life Science Specialties; DW: Dry weight; IP: Intraperitoneal injection; DPPH: 1,1-Diphenyl2-picrylhydrazyl; PBS: Phosphate buffer solution; TNF: Tumor necrosis factor; TP: Total phenol.

\section{Acknowledgements}

Not applicable.

\section{Authors' contributions}

MGM and MSA performed the in vitro experiment. AlH and MAM performed the in vivo experiment and the statistical data. The paper was written by MGM, MSA, AlH, and MAM. All authors have read and approved the manuscript.

\section{Funding}

The authors received no financial support for the research, authorship, and/or publication of this article.

\section{Availability of data and materials}

The data is available and it will be provided to the editor if required.

\section{Declarations}

\section{Ethics approval and consent to participate}

The study protocol was approved by the members of the Medical Research Ethics Committee number (19-104).

\section{Consent for publication}

Not applicable

\section{Competing interests}

The authors declare that they have no competing interests.

\section{Author details}

'Department of Radioisotopes, Nuclear Research Centre, Egyptian Atomic Energy Authority, Cairo, Egypt. ${ }^{2}$ Microbial Biotechnology Department, National Research Centre, Dokki, Giza, Egypt.

Received: 5 May 2021 Accepted: 16 November 2021 Published online: 10 December 2021

\section{References}

1. Sande D, de Oliveira GP, e Moura MAF, de Almeida Martins B, Lima MTNS, Takahashi JA. Edible mushrooms as a ubiquitous source of essential fatty acids. Food Res Int 2019;125:108524.

2. Yilmaz N, Solmaz M, Türkekul I, Elmastaş M (2006) Fatty acid composition in some wild edible mushrooms growing in the middle Black Sea region of Turkey. Food Chem 99:168-174

3. Feeney MJ, Dwyer J, Hasler-Lewis CM, Milner JA, Noakes M, Rowe S et al (2014) Mushrooms and health summit proceedings. J Nutr 144:1128S-1136S

4. Kalaras MD, Richie JP, Calcagnotto A, Beelman RB (2017) Mushrooms: A rich source of the antioxidants ergothioneine and glutathione. Food Chem 233:429-433
5. Huang Q, Liu B, Jiang R, Liao S, Wei Z, Bi Y et al (2019) G-CSF-mobilized peripheral blood mononuclear cells combined with platelet-rich plasma accelerate restoration of ovarian function in cyclophosphamide-induced POI rats. Biol Reprod 101:91-101

6. Luderer U, Eskenazi B, Hauser R, Korach KS, McHale CM, Moran F et al (2019) Proposed key characteristics of female reproductive toxicants as an approach for organizing and evaluating mechanistic data in hazard assessment. Environ Health Perspect 127:75001

7. Lee AH, Pasalich M, Su D, Tang L, Binns CW (2013) Mushroom intake and risk of epithelial ovarian cancer in Southern Chinese women. Int J Gynecol Cancer 23

8. Lu W-Y, Zhang T, Zhang D-Y, Li C-H, Wen J-P, Du L-X (2005) A novel bioflocculant produced by Enterobacter aerogenes and its use in defecating the trona suspension. Biochem Eng J 27:1-7

9. Li H-B, Wong C-C, Cheng K-W, Chen F (2008) Antioxidant properties in vitro and total phenolic contents in methanol extracts from medicinal plants. LWT-Food Sci Technol 41:385-390

10. Zeković Z, Vidović S, Mujić I (2010) Selenium and zinc content and radical scavenging capacity of edible mushrooms Armilaria mellea and Lycoperdon saccatum. Croat J Food Sci Technol 2:16-21

11. Ataya K, Moghissi K (1989) Chemotherapy-induced premature ovarian failure: mechanisms and prevention. Steroids 54:607-626

12. Fridovich I (1986) Superoxide dismutases. Adv Enzym Relat Areas Mol Biol 58:61-97

13. Beutler E (1975) Red cell metabolism. A Man Biochem Methods:11-12

14. Beutler E (1984) In red cell metabolism. A Man Biochem. Methods

15. Jarrell J, YoungLai EV, Barr R, O'Connell G, Belbeck L, McMahon A (1986) An analysis of the effects of increasing doses of ionizing radiation to the exteriorized rat ovary on follicular development, atresia, and serum gonadotropin levels. Am J Obstet Gynecol 154:306-309

16. Bohlinger I, Leist M, Gantner F, Angermüller S, Tiegs G, Wendel A (1996) DNA fragmentation in mouse organs during endotoxic shock. Am J Pathol 149:1381

17. Bova GS, Eltoum IA, Kiernan JA, Siegal GP, Frost AR, Best CJM et al (2005) Optimal molecular profiling of tissue and tissue components. Mol Biotechnol 29:119-152

18. Maciel GAR, Baracat EC, Benda JA, Markham SM, Hensinger K, Chang RJ et al (2004) Stockpiling of transitional and classic primary follicles in ovaries of women with polycystic ovary syndrome. J Clin Endocrinol Metab 89:5321-5327

19. Mandl AM (1951) The phases of the oestrous cycle in the adult white rat. J Exp Biol 28:576-584

20. Daba AS, Kabeil SS, Botros WA, El-Saadani MA (2008) Production of mushroom (Pleurotus ostreatus) in Egypt as a source of nutritional and medicinal food. World J Agric Sci 4:630-634

21. Jin Z, Hou Q, Niu T (2020) Effect of cultivating Pleurotus ostreatus on substrates supplemented with herb residues on yield characteristics, substrates degradation, and fruiting bodies' properties. J Sci Food Agric 100:4901-4910

22. Bellettini MB, Fiorda FA, Maieves HA, Teixeira GL, Ávila S, Hornung PS et al (2019) Factors affecting mushroom Pleurotus spp. Saudi J Biol Sci 26:633-646

23. Turkoglu A, Duru ME, Mercan N, Kivrak I, Gezer K (2007) Antioxidant and antimicrobial activities of Laetiporus sulphureus (Bull.). Murrill. Food Chem 101:267-273

24. Liu Y-T, Sun J, Luo Z-Y, Rao S-Q, Su Y-J, Xu R-R et al (2012) Chemical composition of five wild edible mushrooms collected from Southwest China and their antihyperglycemic and antioxidant activity. Food Chem Toxicol 50:1238-1244

25. Rengasamy KRR, Khan H, Gowrishankar S, Lagoa RJL, Mahomoodally FM, Khan Z et al (2019) The role of flavonoids in autoimmune diseases: therapeutic updates. Pharmacol Ther 194:107-131

26. Palacios I, Lozano M, Moro C, D’arrigo M, Rostagno MA, Martínez JA et al (2011) Antioxidant properties of phenolic compounds occurring in edible mushrooms. Food Chem 128:674-678

27. Ramos M, Burgos N, Barnard A, Evans G, Preece J, Graz M et al (2019) Agaricus bisporus and its by-products as a source of valuable extracts and bioactive compounds. Food Chem 292:176-187

28. Ferreira ICFR, Baptista P, Vilas-Boas M, Barros L (2007) Free-radical scavenging capacity and reducing power of wild edible mushrooms 
from northeast Portugal: individual cap and stipe activity. Food Chem 100:1511-1516

29. Boonsong S, Klaypradit W, Wilaipun P (2016) Antioxidant activities of extracts from five edible mushrooms using different extractants. Agric Nat Resour 50:89-97

30. Aryal S, Baniya MK, Danekhu K, Kunwar P, Gurung R, Koirala N (2019) Total phenolic content, flavonoid content and antioxidant potential of wild vegetables from Western Nepal. Plants 8:96

31. Mohamed SA, Shalaby SM, Abdelaziz M, Brakta S, Hill WD, Ismail $N$ et al (2018) Human mesenchymal stem cells partially reverse infertility in chemotherapy-induced ovarian failure. Reprod Sci 25:51-63

32. Spears N, Lopes F, Stefansdottir A, Rossi V, De Felici M, Anderson RA et al (2019) Ovarian damage from chemotherapy and current approaches to its protection. Hum Reprod Update 25:673-693

33. Nguyen QN, Zerafa N, Liew SH, Findlay JK, Hickey M, Hutt KJ (2019) Cisplatin-and cyclophosphamide-induced primordial follicle depletion is caused by direct damage to oocytes. Mol Hum Reprod 25:433-444

34. Visser JA, Themmen APN (2014) Role of anti-Müllerian hormone and bone morphogenetic proteins in the regulation of FSH sensitivity. Mol Cell Endocrinol 382:460-465

35. Kado R, McCune WJ (2020) Ovarian protection with gonadotropin-releasing hormone agonists during cyclophosphamide therapy in systemic lupus erythematosus. Best Pract Res Clin Obstet Gynaecol 64:97-106

36. de Almeida Chuffa LG, Seiva FRF, Cucielo MS, Silveira HS, Reiter RJ, Lupi LA (2019) Mitochondrial functions and melatonin: a tour of the reproductive cancers. Cell Mol Life Sci 76:837-863

37. Ciani F, Cocchia N, d'Angelo D, Tafuri S (2015) Influence of ROS on ovarian functions. New Discov Embryol 3:1-34

\section{Publisher's Note}

Springer Nature remains neutral with regard to jurisdictional claims in published maps and institutional affiliations.

\section{Submit your manuscript to a SpringerOpen ${ }^{\circ}$ journal and benefit from:}

- Convenient online submission

- Rigorous peer review

- Open access: articles freely available online

- High visibility within the field

- Retaining the copyright to your article

Submit your next manuscript at $\gg$ springeropen.com 